\title{
Person-marking in Máku
}

\author{
Chris Rogers \\ Brigham Young University
}

In Máku (an extinct language isolate), person marking is encoded by pronominal elements that are attached to bound pronominal roots, possessed nouns, and as subject and object argument agreement reference on verbs. However, when the contrasts between the various person-markers and their behaviors in the language are considered the system does not fit easily into the traditional analysis of three persons and two numbers. Rather, the organization of and relationships between the pronominal elements in Máku reveals a system based on the distinction of three persons (first, second and third), a two-way quantitative distinction (singular and non-singular), and a two-way qualitative distinction (homogenous speech-act-participants or heterogeneous speech-actparticipants). Furthermore, some of the syncretisms which provide evidence for this description are crosslinguistically commonplace while others are rare or unattested, as suggested in Cysouw (2003) and Siewierska (2004). This article provides the facts of person marking in Máku and motivates a language-specific description of the paradigm.

\section{Introduction}

The purpose of this article is to describe and discuss the organization of and relationships between the elements comprising the person-marking paradigms in Máku (an under-described, extinct northern Amazonian language; Glottocode: maku1246). Analyses of person-marking in the languages of the world has been an established descriptive activity for a long time (see Cysouw 2003 and Siewierska 2004 for two recent overviews). These analyses have traditionally focused on the correspondence(s) between the language forms used to mark person distinctions and their functions within the grammatical system if the language. In these descriptive analyses, specific person-marking contrasts have often been posited to exist which reflect necessary communicative functions cross-linguistically. Thus, a distinction between a speaker, an addressee, and an 'other' (i.e., first, second, and third persons respectively) are common place. Similarly, a quantitative distinction between one referent and more than one referent are also common (i.e., singular and plural respectively). This has resulted in a methodological heuristic in the analysis of personmarking where paradigms are understood as exhibiting three persons and two numbers, as shown in Table 1. Using this tool, the task of describing the person-marking system of a language simply requires the blank cells to be filled with the morphemes used by a specific language.

\begin{tabular}{|l|l|l|}
\hline & $\begin{array}{l}\text { Singular } \\
\text { (one referent) }\end{array}$ & $\begin{array}{l}\text { Plural } \\
\text { (more than one referent) }\end{array}$ \\
\hline First (speaker) & & \\
\hline Second (addressee) & & \\
\hline Third (other) & & \\
\hline
\end{tabular}

Table 1. Traditional functional contrasts in person-marking

The system suggested in Table 1 is useful in that in provides a relatively easy way to compare person-marking systems crosslinguistically (i.e., the labels in the first column and first row of Table 1 are useful comparative concepts, see Haspelmath 2010). However, one drawback to this traditional model of analyzing person-marking paradigms is that it potentially allows for a large 
amount of syncretisms in a given language's paradigm, where a form has one or more different functions (e.g., you in English functions as both the second person singular and the second person plural pronoun). In this vein, and starting at least with the Quechua grammar written by Domingo de Santo Tomás (1555), where what is now called clusivity was first recognized, and then continued more recently with seminal research into the crosslinguistic correspondence of linguistic forms and functions in person marking (Cysouw 2003, Siewierska 2004, Filimonova 2005), this traditional approach to person paradigms has shifted.

Based on the large number of language descriptions from around the world, it is now clear that the language-specific contrasts (either in forms or functions) suggest more accurate descriptions of person-marking systems which do not necessarily follow the traditional model suggested in Table 1. This means that no person-marking distinction should be considered a part of a language a priori (i.e., no cell in Table 1 should be considered a universal distinction for all languages), but rather should be motivated based on the distinctions represented by the contrasts in a given language. Cysouw (2005:74), for example, suggests that in an empirical study of person forms "the proper null-hypothesis should be that formally homophonous morphemes in a language have a unified meaning -- until reasons are found that prove that this hypothesis wrong". Under this perspective, the syncretisms represented in an analysis based on the traditional model in Table 1, often (though not always) suggest that a specific meaning, or contrast, is not relevant for a specific language's grammatical system.

This article is descriptive in nature and presents the facts for person-marking in Máku. The analysis below is based only on those contrasts that are exhibited in the language. Specifically, it is claimed below that the pronominal elements in Máku reveal a system based on the distinction of three persons (first, second and third), a two-way quantitative distinction (singular and nonsingular), and a two-way qualitative distinction (homogenous speech-act-participants or heterogeneous speech-act-participants). Consequently, the traditional descriptive analysis of person (as in Table 1) is not specifically representative of Máku, and a new descriptive paradigm is suggested.

After a brief description of the ecology of Máku and the resources available on the language in section 2, this article has two main divisions. First, in section 3, a description of the patterns of person-marking as used in independent pronouns, noun possession and verbal agreement is presented. This description presents the known facts about the formal and functional contrasts for Máku person-marking mostly following a traditional format (see above). The goal here is to provide a foundation of comparison with other languages in the world (and with which readers might be familiar). Then, in section 4, the general principles (i.e., language specific contrasts) of organization and architecture for Máku person-marking is considered, followed by a short conclusion.

\section{Ecology (and history) of Máku}

Máku is an Amazonian language isolate that was previously spoken by a small group of people, in the vicinity of the Auaris (or Auari) River located in the extreme northwest of the state or Roraima, Brazil (Koch-Grünberg 1913:457, 1917:48, 170). The speakers of this language referred to themselves as jukude-itse [zokude-itse] 'people-PL'. It is commonplace to refer to the language as $\mathrm{Máku}^{1}$ in the linguistic literature, reserving the autonym, consequently, for the cultural group of

\footnotetext{
${ }^{1}$ The label 'Máku' is a pejorative exonym used by the Arawakan speaking peoples of the Içana-Vaupés basin to refer to various nomadic populations of this region (Koch-Grünberg 1906:877). This has resulted in confusion in that
} 
speakers of this language. The jukude-itse lived a semi-nomadic lifestyle, occasionally practicing slash-and-burn agriculture, in an environment of high levels of language contact, and were known as successful traders throughout the region (Koch-Grünberg 1917:48, and Rogers and Zamponi in preparation). The recorded history of the jukude-itse is marked by a steady decline in speakers, domains of use, and in valorization of their language. This was the result of social pressures caused by other cultural groups in the Amazonian region and more recently by national and international pressures of conformity and globalization.

Rice (1928) reported 50 speakers of the language in two malocas (i.e., long houses) at the head of the Uraricoera river and a region between the mouths of the Aracaçá (Aracasa) and the Aruaris rivers, respectively. Migliazza (1980:115), based on fieldwork with the last Máku speakers, reported that sometime before 1950 repeated attacks by the Kasirapai (a Ninam-speaking Yanomami group) on the jukude-itse left one family of Máku speakers, of eight or nine people. In 1969, there were only two speakers of Máku remaining, Sinfrônio Magalhães and his sister Maria Magalhães. Sinfrônio had no children and Maria raised her children as speakers of Portuguese (Migliazza 1965:18). By the year 2000, both Sinfrônio and Maria has died and Máku ceased to be spoken. Currently there are no heritage language learners or cultural groups that claim Máku ancestry (i.e., there is nobody claiming to be a descendant of the jukude-itse).

Fortunately, information on this language has been recorded sporadically throughout the twentieth century. This information consists of wordlists, field notes, audio recordings, and sketches and profiles of the grammatical system - some of these remaining unpublished (KochGrünberg 1906, 1911, 1913, 1917; Loukotka 1968:151, Migliazza 1958, 1965, 1966 1978, 1980; de Faria 1927a, 1927b; Maciel 1991; Rodrigues 1986:95). Using these resources collectively, a consistent picture of Máku grammar emerges that shows indications of contact with other language groups and various unique grammatical properties when compared to other surrounding languages (see Zamponi and Rogers to appear and Rogers and Zamponi in preparation). ${ }^{2}$ Aside from being a relatively unknown extinct language, as mentioned above, Máku is also a linguistic isolate (Koch-Grünberg 1913:457, Loukotka 1968:151, Migliazza 1965:1, Rodrigues 1986:95), though it is occasionally grouped together as one member of a genetically unrelated language group with two other language isolates Sapé and Uruak (Greenberg 1987:383, Kaufman 1994: 60-61).

In light of the status of Máku as an extinct language with only sporadic documentation, it is likely that gaps exist in the available information on the language. Such gaps have the potential of engendering speculation about the behavior of grammatical elements rather than a confident empirical discussion. While the Máku person marking system appears to be fairly comprehensively documented in the available resources and should present minimal problems in this article, when working with an extinct language - where no new data can be collected and speaker intuitions cannot be checked - any analysis presented is best restrained only to the most obvious conclusions (and descriptions) possible - leaving theoretical implications for subsequent discussions. This restraint and preference for descriptive analysis has been the motivation for the presentation,

various language groups in the area are referred to by this or similar names. For example, Makú is a non- genealogical grouping of the northwest Amazon that has long been assumed to include the languages Hup, Yuhup, Dâw, and Nadëb (the Nadahup family), the sisters Kakua and Nukak (the Kakua-Nukak family), and Puinave (an isolate). Similarly, Mako (or Maco) refers to a language of the Sáliban family (closely related to Piaroa) spoken by agroup located along the Ventuari river and its tributaries (state of Amazonas, Venezuela).

${ }^{2}$ These resources and the current article are funded in part by NSF/DEL grant No. 1524606, Synchronic, diachronic and typological description of Máku. All of the Máku resources are archived at the Archive of the Indigenous Languages of Latin America (http//:www.ailla.utexas.org). 
format, and organization of the discussion below.

\section{Máku person-marking}

Words in Máku belong to one of nine grammatical classes: nouns, pronouns, verbs, adverbs, conjunctions, particles, interjections, and ideophones (see Zamponi and Rogers to appear). Of these only nouns, pronouns, and verbs are used in conjunction with person-marking affixes, where they are used to mark word formation, possession or verbal agreement, respectively. The paradigms used for each of these three grammatical functions are largely identical, though differences in each paradigm suggest that they should be treated separately.

\subsection{Person-marking in independent pronouns}

Like other languages in the world, and specifically in the Amazon (see Siewierska 2004:19 inter alia), in Máku independent pronouns are morphologically complex and consist of a bound pronominal root and one person marker which references a specific person/number combination. There are two pronominal roots $*_{n e}$ and $*_{o j}$ used with non-third persons (i.e., speech-act participants) and third persons (i.e., non-speech-act participants), respectively. Three persons and three numbers can be distinguished in the affixes attached to these pronominal roots, listed in Table 2. The person marking affixes are given in bold and the surface pronunciation is given in brackets where there is a notable difference from the citation form.

\begin{tabular}{|c|c|c|c|c|}
\hline & singular & dual & plural & \\
\hline & & teke-ne & teke-ne-nu?u & exclusive \\
\hline & & tse-ne & tse-ne-nu?u & inclusive \\
\hline 1 & te-ne & \multicolumn{2}{|c|}{ te-ne-nu?u } & unified \\
\hline 2 & e-ne & \multicolumn{2}{|c|}{ e-ne-nu?u } & \\
\hline 3 & oj-e [ozə] & \multicolumn{2}{|c|}{ oj-tse [ ${ }^{\mathrm{w}}$ ojtse] } & \\
\hline
\end{tabular}

In this paradigm the distinction between third and non-third persons is marked in three ways. This distinction is marked once through a choice of pronominal roots, ${ }^{*} n e$ vs. ${ }^{*} o j$, a second time through the position of the person affixes, (non-third person affixes are attached as prefixes while third person affixes are attached as suffixes), and a third time through the use of the plural suffix -nu? $u$ (this suffix is only used with non-third person referents - see below for additional examples). Consequently, the distinction between third person and non-third persons (or speech-act participants vs. non-speech-act participants) is considered a significant organizational element for the description of Máku independent pronouns.

The fact that the inclusive and exclusive are inherently dual, in contrast to the use of the plural suffix $-n u ? u$ which indicates numbers greater than two, can be seen in the following example sentences taken from the available resources on the language. ${ }^{3}$

\footnotetext{
${ }^{3}$ Abbreviations for this article include: $1=$ first person, $2=$ second person, $3=$ third person, NOM $=$ nominal, vERB $=$ verbal, $\mathrm{PL}=$ plural, $\mathrm{PERF}=$ perfective, DIST.FUT $=$ distant future, $\mathrm{HAB}=$ habitual, $\mathrm{PRON}=$ pronominal, $\mathrm{SUBJ}=$ subject, $\mathrm{OBJ}=$ object, $\mathrm{COLL}=$ collective, $\mathrm{NA}=$ not attested
} 
(1) teke-ne teke-mine

1+3-PRON 1+3-house

'our house' (another's and mine)

(2) tse-ne tse-mine

1+2-PRON 1+2-house

'our house' (yours and mine)

(3) teke-ne-nu?u teke-bote-nu?u-na

1+3-PRON-PL 1+3-big-PL-HAB

'We all are big/great' (not you).

(4) tse-ne-nu?u tse-bote-nu?u-na

1+2-PRON-PL 1+2-big-PL-HAB

'We are all are big/great' (not others).

(5) te-ne-nu?u te-kuduma-nu?u-na

1-PRON-PL 1-be.good-PL-HAB

'We are all good'.

Based on the distinction between these sentences the inclusive and exclusive pronouns are understood principally as indicating duality. In the case of the exclusive, the referents are the speaker and a single other person not including the addressee (as in example 1). In the case of the inclusive, the referents are the speaker and a single addressee but no other person (as in example 2). However, both of these pronouns can be used in conjunction with the plural suffix to indicate referent groups greater than two but still indicating the same value of clusivity (i.e. tekenenu? $u$ is exclusive with three or more referents and tsenenu? $u$ is inclusive with three or more referents, as in examples 3 and 4 respectively). The unified first person plural form tenenu? $u$ includes referents to the speaker, any addressee(s), and any other people, and so by default is quantitatively larger than a dual, (as in example 5). These number distinctions are indicated in the descriptive labels in the first row of Table 2 .

The syncretisms in the paradigm in Table 2, are noteworthy. Specifically, the form te is used both as the marker of first person singular and unified first person plural; the form $e$ is used for second person singular, second person plural, and third person singular (though as prefixes in second person functions and as a suffix in the third person singular function); and the form tse is used both as a marker of inclusivity and third person plural (though as a prefix or suffix respectively). Working under the hypothesis suggested by Cysouw (2005:74), and mentioned in section 1 above, without adequate motivations, the contrasts that keep these syncretisms apart should be abandoned and conflated into a single unified meaning. That is, for example, since the morpheme tse functions as both a marker of inclusive (dual) and third person plural, its meaning might encompass both of the distinctions, rather than being two homophonous morphemes with distinct meanings.

The descriptions and cross-linguistic comparisons of syncretisms in person-marking suggest that such a conflated description of the meanings of some forms is preferred in many languages. That is, both of the horizontal syncretisms (between singular forms and plural forms) and the 
vertical syncretisms (between different singular forms or different plural forms) are common crosslinguistically and have been treated as having a unified meaning (Cysouw 2003). However, the vertical syncretism between an inclusive form and a third person plural form is unattested for the world's languages (Cysouw 2003). The importance of this syncretism to a Máku-specific organization of the person-marking paradigm and its comparison to other languages will be discussed in section 4 below, after the entire Máku system is discussed.

\subsection{Person-marking in noun possession}

Nominal possession is generally marked using the same paradigm of person markers indicated above for the independent pronouns. However, in noun possession there are two separate person paradigms representing an alienable/inalienable distinction. Only the forms for the third person singular possession are different in each of these distinctions, the remaining person marker forms being identical to those shown in Table 2 above. Inalienable possession does not mark the third person singular function (shown here as a null prefix) and is used mostly for kinship terms and terms that denote body parts and the parts of plants. Alienable possession marks the third person singular function with $e$ - (just like for pronoun formation) and is used for all other nouns. It is difficult to give accurate counts of the relative number of nouns marked with inalienable possession or alienable possession, because not all nouns recorded for the language are included with possession inflection paradigms. However, of the 627 noun roots recorded for the language 11 show inalienable possession in third person singular, and 5 show alienable possession in the third person singular. These are listed in (6) and (7), respectively.

(6) List of inalienably possessed nouns

$\begin{array}{lll}\text { a. } & \text { batsi } & \text { 'leg' } \\ \text { b. nabuine } & \text { 'wife' } \\ \text { c. loke } & \text { 'father' } \\ \text { d. one } & \text { 'mother' } \\ \text { e. kote } & \text { 'feather' } \\ \text { f. pi } & \text { 'nose' } \\ \text { g. basaku } & \text { 'foot, knee' } \\ \text { h. } & \text { wat } f & \text { 'mouth' } \\ \text { i. } & \text { isa } & \text { 'liver' } \\ \text { j. tfimu } & \text { 'skin, bark' } \\ \text { k. } & \text { isakotfi } & \text { '(parrot) claw' }\end{array}$

(7) List of alienable possessed nouns
a. mine 'house'
b. kidialo 'canoe'
c. katsu 'horn'
d. timala 'arrow'
e. tfimala oba 'bow'

Despite the paucity of information about noun possession in Máku, the recorded paradigms are consistent for all nouns within each subclass. Table 3 shows an example of an inalienably possessed noun basaku 'foot'. Table 4 shows an example of an alienably possessed noun tsimala 
uba 'bow'.

\begin{tabular}{|c|c|c|c|}
\hline & singular & plural & \multirow{5}{*}{$\begin{array}{l}\text { exclusive } \\
\text { inclusive }\end{array}$} \\
\hline \multirow[t]{2}{*}{1} & & teke-basaku & \\
\hline & te-basaku & tse-basaku & \\
\hline 2 & e-basaku & e-basaku(-nu?u) & \\
\hline 3 & Ø-basaku & tse-basaku & \\
\hline
\end{tabular}

\begin{tabular}{|l|l|l|}
\hline & singular & plural \\
\hline \multirow{2}{*}{1} & & teke-tsimala uba \\
\cline { 2 - 3 } & te-tsimala uba & tse-tsimala \\
executive \\
inclusive
\end{tabular}

Other than the difference in the third person singular form in the inalienable paradigm, there are two other components that both of these paradigms share which is different than the pronoun formation paradigm discussed above. First, the nominal possession paradigm does not exhibit a distinction between plural and dual forms. That is, when used as markers of possession the inclusive form $t$ se refers to the speaker and any addressee(s) and the exclusive form teke refers to the speaker and any number of people not including addressee(s).

(8) tekene tekepi

1+3-PRON 1+3-nose

'our noses' (theirs, sg. and pl. and mine)

(9) tsene tsepi

1+2-PRON 1+2-nose

'our noses' (yours, sg. and pl., and mine)

Similarly, there is no separate unified form which would include the speaker, the addressee and any other person(s) recorded for noun possession, as it is for the pronouns above. It is possible that Máku did have the same distinctions for nominal possession as it did for the independent pronouns and that the patterns that can be observed are simply a consequence of the data available in the resources. However, no resource on the language indicates any possibility of these forms. The discussion here takes the perspective that that there are fewer form/function contrasts in the personmarking paradigm for nominal possession than there are for independent pronouns. However, this issue remains unresolved.

Second, note that unlike the pronouns the plural suffix $-n u ? u$ is used for second person plural marking only. This appears to be an optional grammatical device, as some examples glossed with a second person plural possessor use it, while others do not. However, it can be noted that the translations and glosses of a few example sentences suggests a collective reading when the plural suffix is used, as seen in (10) and (11). 
e-ne-nu?

2-PRON-PL 2-canoe

'your (pl.) canoe' (i.e., speaking of one canoe not owned collectively by various people)

e-ne-nu? e-kidialu-nu?u

2-PRON-PL 2-canoe-PL

'your (pl.) canoe' (i.e., speaking of one canoe owned collectively by various people)

Since there is no dual/plural distinction in the person markers used for possession, the second person form is the only ambiguous element for the category of number (i.e., only the second person shows horizontal syncretism in nominal possession). The use of this suffix, then, might be a strategy for disambiguating this particular construction, but be unnecessary for other personmarking contrasts.

Lastly, two vertical syncretisms can be observed. First, in the alienable paradigm the form $e$ is used for three distinct meanings: second person singular, second person plural, and for third person singular (just like for the pronouns). In contrast, in the inalienable paradigm the form $e$ is used for only two distinct meanings: second person singular and second person plural. Second, the form tse is used for both the inclusive and the third person plural meanings (like the pronouns) and is always used as a prefix (unlike the pronouns).

\subsection{Person-marking in verb agreement}

Person marking is also exhibited for subject-verb agreement for all verbs and object agreement for transitive verbs. Both types of verbal agreement are required by all verbs in declarative clauses; other clause types, such as imperative clauses, do not exhibit subject or object agreement and are not represented in this article. The person/number forms used to mark both types of verb agreement are generally the same as those for pronoun formation and noun possession above, though there are some notable differences. Subject and object agreement are discussed in turn.

Table 5 represents the subject agreement inflections for the verb $\mathrm{kaj}$ 'to stand' with the person markers in bold (the abbreviation NA indicates that a specific form is not attested in the specific verb paradigm, having not been recorded in the Máku resources, though there are examples of this form with other verbs).

\begin{tabular}{|c|c|c|c|c|}
\hline & singular & dual & plural & \multirow{6}{*}{$\begin{array}{l}\text { exclusive } \\
\text { inclusive } \\
\text { unified }\end{array}$} \\
\hline \multirow{3}{*}{1} & & teke-kaj & NA & \\
\hline & & tse-kaj & tse-kaj-nu?u & \\
\hline & te-kaj & \multicolumn{2}{|c|}{ te-kaj-nu?u } & \\
\hline 2 & ke-kaj & \multicolumn{2}{|c|}{ ke-kaj-nu?u } & \\
\hline 3 & Ø-kaj & \multicolumn{2}{|c|}{ tse-kai(-pu) } & \\
\hline
\end{tabular}

Similar to the formation of pronouns and inalienable noun possession discussed above, subjectverb agreement distinguishes three numbers: singular, dual, and plural. In addition, verb personmarking exhibits a unified first person plural form similar to the pronominal paradigm discussed above. Also, like the pronominal paradigm, the inclusive tse and the exclusive teke forms have 
strictly dual referents, and only non-third person markers are marked for plurality using the suffix $-n u$ ? $u$.

teke-ne teke-le-dja

1+3-PRON 1+3-fall-PERF

'We (exclusive, dual) fell'

(teke-ne-nu?u) teke-le-dja-nu?u

(1+3-PRON-PL) 1+3-fall-PERF-PL

'We (everyone but the hearer) fell'

However, unique to verb agreement, is that fact that the third person plural meaning is always marked with $t$ se and optionally with the suffix - $p u$. The exact function of this suffix is unknown as it is represented inconsistently in the Máku resources, though there are some minimally contrastive examples which indicate it may have served as a marker of collectivity in the verbal action, as shown in examples (14) and (15).

wojtse taba tse-bule-pu-dia

they stick 3PL-burn-COLL-PERF

'They (collectively) burnt the stick.'

wojtse taba tse-bule-dia

they stick 3PL-burn-PERF

'They (individually) burnt the stick.'

Lastly, like the inalienable nominal possession, three singular person forms are distinguished in verb agreement markers, i.e., first, second and third. The difference is that for verb agreement second person singular is marked with $k e$ - and in inalienable possession second person singular is marked with $e$-.

Subject-verb agreement in Máku may have potentially been cross-cut by a three-way verb class system which determined the position of the marker in relation to the verb root. While for a majority of verb roots, person markers are attached as prefixes to the root, a small number of verbs show them either as infixes after the first syllable of the root or as suffixes after the root. It is not clear how pervasive this class system was in Máku grammar, and the position of the person markers does not appear to affect either the grammatical function, the semantic connotation of the verbal action or the formal representation of the person markers themselves. Table 6 shows the verb inene 'to be afraid' which exhibits person marking infixes.

\begin{tabular}{|c|c|c|c|}
\hline & singular & dual & plural \\
\hline \multirow[t]{3}{*}{1} & & $\mathrm{i}<$ teke $>$ nene & NA \\
\hline & & NA & $\mathrm{i}<$ tse $>$ nene-nu?u \\
\hline & $\mathrm{i}<$ te $>$ nene & \multicolumn{2}{|c|}{$\mathrm{i}<$ te $>$ nene-nu?u } \\
\hline 2 & $\mathrm{i}<\mathbf{k} \mathbf{e}>$ nene & \multicolumn{2}{|c|}{$\mathrm{i}<\mathbf{k e}>$ nene-nu?u } \\
\hline 3 & $\mathrm{i}<\varnothing>$ nene & \multicolumn{2}{|c|}{$\mathrm{i}<$ tse $>$ nene } \\
\hline
\end{tabular}

exclusive inclusive unified 
Only three verbs are recorded as exhibiting person-marking through infixation, with inene 'to be afraid' (seen above) recorded with the most complete information. The other two verbs are kutsi 'to wash' and da?ina 'to bring' shown in Table 7 and Table 8, respectively.

\begin{tabular}{|c|c|c|c|c|}
\hline & singular & dual & plural & \\
\hline 1 & & ku $<$ teke $>$ tsi & NA & exclusive \\
\hline & & $\mathrm{ky}<\mathrm{tse}>$ tsi & NA & inclusive \\
\hline & $\mathrm{ku}<\mathrm{te}>\mathrm{tsi}$ & \multicolumn{2}{|c|}{$\mathrm{ku}<$ te $>$ tsi-nu?u } & unified \\
\hline 2 & NA & \multicolumn{2}{|c|}{ NA } & \\
\hline 3 & $\mathrm{ku}<\varnothing>$ tsi & \multicolumn{2}{|c|}{$\mathrm{ku}<$ tse $>$ tsi } & \\
\hline
\end{tabular}

\begin{tabular}{|c|c|c|c|c|}
\hline & singular & dual & plural & \\
\hline 1 & & NA & NA & exclusive \\
\hline & & NA & NA & inclusive \\
\hline & da?i $<$ te $>$ na & \multicolumn{2}{|c|}{ NA } & unified \\
\hline 2 & da?i $<\mathbf{k e}>$ na & \multicolumn{2}{|c|}{ NA } & \\
\hline 3 & da?i $<\varnothing>$ na & \multicolumn{2}{|c|}{ NA } & \\
\hline
\end{tabular}

These have been analyzed as containing infixes for two reasons (see Rogers and Zamponi in preparation), first the position of the person markings consistently occurs after the first syllable of the root, and second because no other element of the word can be shown to have grammatical meanings. For example, the [i] in the first part of $i<t e>n e n e$ 'I am afraid' has no known grammatical meaning in the language.

Person-marking being exhibited as suffixes on verb roots is exhibited on only two verb roots in the Máku resources, kute 'I see', bukuluteke 'We (excl.) hunt'. Table 9 shows the verb ku 'to see' which exhibits the most complete information of person marking as suffixes, and Table 10 show the available information on bukulu 'to hunt'.

\begin{tabular}{|l|l|l|l|}
\hline & singular & dual & plural \\
\hline \multirow{3}{*}{1} & & ku-teke & NA \\
\cline { 2 - 4 } & & ku-tse & ku-tse-nu?u \\
\cline { 2 - 4 } & ku-te & \multicolumn{2}{|c|}{ NA } \\
\hline 2 & ku-se-ke & \multicolumn{2}{|c|}{ NA } \\
\hline 3 & ku-se-ke? & \multicolumn{2}{|c|}{ ku-tse } \\
\hline
\end{tabular}

exclusive

inclusive unified

\begin{tabular}{|l|l|l|l|}
\hline & singular & dual & plural \\
\hline 1 & & bukulu-teke & NA \\
\hline & & NA & bukulu-tse-nu?u \\
\hline & bukulu-te & NA \\
\hline 2 & NA & NA \\
\hline 3 & bukulu-se-ke? & bukulu-tse(-pu) \\
\hline \multicolumn{2}{|c|}{ Table 10. Inflection of bukulu 'to hunt' } \\
\hline
\end{tabular}

exclusive

inclusive unified

It can be noted that the third person singular form in both Table 9 and Table 10 is marked using 
the verbal agreement second person singular form $k e$. This does not match any other verb paradigm, where $\varnothing$ is consistently used for third person singular meanings. Unfortunately, additional paradigms of verbs where the person markers are attached as suffixes are not available. It is unclear if using $k e$ for third person agreement (as show above) was a speaker error (possibly as a result of language attrition), is a representation of analytical error (such as a typo in making field notes), or served some grammatical function. The use of this form for the third person singular function is, consequently, marked with a question mark '?'. The general Máku system of personmarking contrasts suggested in section four below would be consistent withn this form as an error.

Furthermore, the function of the suffix -se preceding the person marker in these verb inflection paradigms also remains unknown. However, it seems to correlate to an unknown direct object in other examples - making it appear to have a valency decreasing function.

ene e-lila-se

you 2-pull-?

'you (sg.) pull (something)'

tene te-ko-se

I 1-hit-?

'I hit (something)'

In general, the subject-verb agreement markers (whether they are used as prefixes, infixes or suffixes) show a consistent organization. There is syncretism of the form te (used for first person singular and unified first person plural), the form ke (used for second person singular and plural), and the form tse (used for inclusive and third person plural). These are similar to what has been presented above for the pronominal and nominal paradigms.

Table 11 represents the object agreement markers used for transitive verbs. These are always used as prefixes and are attached furthest from the transitive verb root (i.e., they precede subject agreement prefixes in linear order), see examples (18) through (23).

\begin{tabular}{|c|c|c|c|}
\hline & singular & dual & \multirow{2}{*}{$\frac{\text { plural }}{\text { NA }}$} \\
\hline 1 & & teke- & \\
\hline & & tse- & NA \\
\hline & te- & \multicolumn{2}{|c|}{ NA } \\
\hline 2 & e- & \multicolumn{2}{|c|}{ e-...-nu?u } \\
\hline 3 & $\varnothing-$ & $\varnothing-$ & \\
\hline
\end{tabular}

tene e-te-ku-nu?u-diba

I 2.OBJ-1.SUBJ-hit-PL-DIST.FUT

'I will hit you (pl.).'

ene te-e-ku-diba

you 1.OBJ-2-SUBJ-hit-DIST.FUT

'You will hit me.' 
ojtse te- $\varnothing-k u$-diba

they 1.OBJ-3.SUBJ-hit-DIST.FUT

'They will hit me.'

jo?wi teke-Ø-keby-dia

dog 1+3.OBJ-3.SUBJ-bite-PERF

'The dog bit us (exclusive).'

oja jo?wi Ø-Ø-keby-dia

he dog 3.OBJ-3.SUBJ-bite-PERF

'The dog bit him.'

jo?wi Ø-Ø-keby-dja oj-tse

dog 3.OBJ-3.SUBJ-bite PRON-3PL

'The dog bit them'

The number of missing pieces of the paradigm represented in Table 11 is noteworthy. It is unclear if the distinction between plural and dual function was not necessary (as for noun possession described above) or if these gaps simply represent missing information. Similarly, this is the only paradigm which shows a null form for the third person plural meaning (all others have the form $t s e$ ). It is unclear if this means that there was no third person marking or if it was actually a phonetically empty prefix. Other than this, this paradigm looks identical to the forms and organization in the inalienable noun possession paradigm discussed above.

\section{The Máku person-marking paradigm}

One way of describing the person-marking paradigms exhibited in any language is based on the commonly accepted distinctions between three persons and two numbers. This is a useful descriptive heuristic as it suggests a straightforward comparison of form and meaning contrasts crosslinguistically (see for example the discussion of the value of crosslinguistically comparative concepts in Haspelmath 2010). However, often the resulting paradigmatic tables are shown to have gaps, or syncretisms (i.e., homophonies) where a specific distinction is not exhibited in a given language. This often results in a valid general, crosslinguistic analysis but a poor language-specific analysis because the unique organizational parameters and paradigmatic distinctions are ignored (see Cysouw 2003). The language-specific (not general) analysis can, however, lead to a greater understanding about the unique grammatical architecture of a language and the distinctions relevant to the speakers of a language. In this section a descriptive analysis of Máku is presented following the facts presented in the previous section.

Specifically, the goal of this section is to discuss the general organizational principles observed in the person marking paradigms in Máku described above. This section, consequently, presents an analysis of person marking that focuses on the contrasts between the forms and functions/meanings in each of the three paradigms presented above. This analysis can be approached from one of two perspectives. First, there is the option of considering homophonic forms with distinct meanings to be unique morphemes. Under this approach, for example, there would be two morphemes you in English - one meaning second person singular and the other 
meaning second person plural. Following this analysis, a paradigm might be described as having homophones accidentally (i.e., with no real grammatical significance) or because of analytical biases (such as the traditional notion of person-marking paradigms discussed in Section 1).

The second option, considered here to be much more valid empirically, is to consider homophonic forms with distinct meanings to be a single morpheme and then suggest a unified meaning which covers all grammatical functions. For example, under this approach, there would be one morpheme you in English meaning 'second person' (covering both singular and plural uses), and the description of the English pronominal paradigm would only list this form once. This approach is considered more empirically sound because it has the potential of a simpler description and is based on actual data. Furthermore, since the Máku data is limited, mostly coming from a single final speaker, with limited historical information available, a general (or diachronic) discussion would be largely speculative and potentially not representative of the language. Consequently, in this section, the data presented above for Máku is analyzed such that homophonous forms are analyzed as the same morpheme unless there is evidence to suggest otherwise. This analysis and discussion will begin with the singular distinctions for each paradigm, precede to the non-singular distinctions, and finally consider the relationships between singular and non-singular distinctions.

In the singular forms, there is a three-way contrast of elements in the paradigms for verbal agreement, inalienable noun possession and object agreement (though the three elements are not identical phonetically in each paradigm), while there is only a two-way contrast of elements in the paradigms for alienable noun possession and independent pronoun formation (i.e., one form has both second person singular and third person singular meanings). Each of these are repeated here for clarification in Table 12, Table 13 and Table 14 respectively.

\begin{tabular}{|l|l|}
\hline 1 & te \\
\hline 2 & ke \\
\hline 3 & $\varnothing$ \\
\hline
\end{tabular}

Table 12. Singular verb agreement

\begin{tabular}{|l|l|}
\hline 1 & te \\
\hline 2 & $\mathrm{e}$ \\
\hline 3 & $\varnothing$ \\
\hline
\end{tabular}

Table 13. Singular inalienable possession and object agreement

\begin{tabular}{|l|l|}
\hline 1 & te \\
\hline $2 / 3$ & e \\
\hline
\end{tabular}

Table 14. Singular pronominal formation and alienable possession

In terms of organization principles, this means that a distinction between second person singular and third person singular is not warranted for all person-marking paradigms in Máku. Rather, for pronominal formation and alienable noun formation the singular meaning contrasts are between first person and non-first person. Crosslinguistically both of these general patterns are well attested in various languages and it is not uncommon for different components of the grammar to exhibit different paradigmatic organizations, such as is represented in these three tables (Cysouw 2003 and Siewierska 2004). The three-way contrast in singular forms is quite common crosslinguistically (as evidenced by the traditional description of person-marking discussed in section (1), and following Cysouw's (2003: 40) terminology can be called the "Latin-type". 
Similarly, Cysouw (2003:41) refers to the type of organization in Table 14 (with meaning distinctions between first person and non-first person) as "Dutch-type homophony". This also appears to be fairly common crosslinguistically for different types of person-marking (Cysouw 2003:53). Dutch, for example, shows this type of organization in verb agreement, as in the sentences in (24) through (26) (data taken from Cysouw 2004:41)

jij loop- $t$ you walk-2/3SG

'You walk.'

\section{jij/zij/het loop- $t$ \\ S/he walk-2/3SG \\ 'S/he walks.'}

Consequently, two general organizational schemas can be easily recognized for the description of the singular person-marking paradigms in Máku. The Latin-type is exhibited in subject agreement, the inalienable noun possession, and object agreement. The Dutch-type is exhibited in pronominal formations and the alienable noun possession.

Similarly, in the non-singular forms, two general organizational schemes can also be recognized. The first is seen in noun possession and possibly object-verb agreement and which exhibits a four-way distinction in forms and meanings, but without a distinction between dual and plural. This is shown in Table 15. The second organizational scheme is seen in subject-verb agreement and pronoun formation and exhibits a four-way distinction in forms and meanings, but includes a distinction between dual and plural. This is shown in Table 16, where '--' means an unused distinction.

\begin{tabular}{|l|l|}
\hline & Plural \\
\hline $1+3$ & teke \\
\hline $1+2$ & tse \\
\hline $2+2$ & - nu?u \\
\hline $3+3$ & tse \\
\hline
\end{tabular}

Table 15. No dual distinction in non-singular forms

\begin{tabular}{|l|l|l|}
\hline & Non-singular/Non-plural & Plural \\
\hline $1+3$ & teke & \multirow{3}{*}{-nu?u } \\
\hline $1+2$ & tse & \\
\hline $1+2+3$ & -- & \\
\hline $2+2$ & -- & tse \\
\hline $3+3$ & -- & \\
\hline
\end{tabular}

Table 16. Dual distinction in non-singular forms

Other person-marking forms used for non-singular meanings in the descriptions in section 3 
above, such as the forms $k e$ and $e$ both meaning 'second person plural' or the form te 'first person unified' are considered homophonous extensions of their singular functions when coupled with the plural suffix $-n u ? u$. Consequently they have not been represented in the non-singular distinctions in these two tables. Importantly, there does not seem to be a hierarchical relationship where one of the singular paradigms entails the occurrence of one of the non-singular paradigms, or vice versa.

Three things are of particular note in the organization of these paradigms. First, the form syncretism between the inclusive and third person plural meanings is of interest. No matter if $t s e$ is considered to be a non-plural form (as in Table 16) or a plural form (as in Table 15), the fact that the same form is used for such disparate semantic functions is worthy of attention. Crosslinguistically, syncretism between a first person plural form and a third person plural form is attested (Cysouw 2003: 155-160). However, in each case cited either the syncretism exists for the exclusive and the third person plural forms, called the "exclusive/3" paradigm by Cysouw (2003:158) - represented in Table 17 with Shuswap plural intransitive verb inflections, or it exists for a combined inclusive and unified first person plural form (in contrast to an exclusive form) and a third person plural form, called the "inclusive/3" paradigm by Cysouw (2003:155) -represented in Table 18 with Huave pronominal affixes.

\begin{tabular}{|c|c|}
\hline $1+3$ & \\
\hline $1+2$ & \multirow[t]{2}{*}{$-\partial t$} \\
\hline $1+2+3$ & \\
\hline $2+2$ & $-ә p$ \\
\hline $3+3$ & \\
\hline
\end{tabular}

Table 17. Shuswap plural intransitive verb inflection (data from Cysouw 2003:158)

\begin{tabular}{|c|c|c|}
\hline $1+3$ & \multicolumn{2}{|c|}{ sa- } \\
\hline $1+2$ & & \\
\hline $1+2+3$ & & \\
\hline $2+2$ & i- & a- \\
\hline $3+3$ & & \\
\hline
\end{tabular}

Table 18. Huave plural pronominal affixes (data from Cysouw 2003:156)

Languages with paradigms which show syncretism between an inclusive $(1+2)$ form and a third person plural $(3+3)$ form, without including a unified meaning, in contrast to an exclusive $(1+3)$ form, as in Máku, are unattested (Cysouw 2003:162 inter alia); though it might be a subtype of the inclusive/3 type, represented in Table 18.

The second thing of note is that the absence of a unique unified first person plural form which would include first, second and third person referents different from the inclusive and exclusive form/functions is typologically noteworthy. In many typologies of person marking systems, a unified form is a prerequisite for an inclusive/exclusive distinction (or one of these). For example, Cysouw's (2003:164) "explicitness hierarchy" suggests that the unified-we distinction is a prerequisite for, and is less marked than, the inclusive/exclusive distinctions and the minimal/augmented inclusive distinctions. While this hierarchy seems to hold generally for languages, Máku does provide a rare exception. In some of the person-marking paradigms there is evidence of inclusive and exclusive forms without a unified plural meaning in the same paradigm. While this does seem to be relevant for the typological possibilities for person-marking paradigms, it should not be considered overly significant. The fact that Máku is an isolate, and the data available leave a number of gaps in our understanding of the language (both synchronically and 
diachronically), suggests other variables could account for this exception. The paradigms, and the analysis suggested above, are valid for Máku, but it is not clear how representative they are of language typologies more generally.

The last thing to note about the organization of non-singular elements is that the inherent quantity of the inclusive and exclusive forms as duals (i.e., non-singular and non-plural) is of relevance. Following, Cysouw (2003:72) and Siewierska (2004:84), a clusivity distinction in a person-marking paradigm can be understood to reflect the nature of the reference (i.e., quality) and not necessarily the number of participants (i.e., quantity). So while an inclusive or an exclusive form may be strictly dual - as it is for some paradigms in Máku - the type of relationship that exists between the two referents may be a better descriptive diagnostic of their particular function within the system. In fact, Siewierska (2004:1-14) suggests that one such qualitative relationship in person-marking paradigms is how the referent(s) of a specific form relates to the speech-act itself, as either participants or non-participants.

Viewed from this perspective the referents of the Máku form teke 'exclusive' have opposing relationships with the speech-act. One referent is a speech-act-participant (i.e., the first person) and one is not (i.e., the third person). The referents of the Maku form tse 'inclusive' and 'third person plural', in contrast have similar relationships with the speech-act. As an inclusive, this form references the speaker and the addresses (both of which are speech-act-participants). As the third person plural, this form references anyone else besides the speaker and the addressee (which would be non-speech-act-participants). These types of relationships are called "heterogeneous" and "homogenous" below, referring to the whether they have opposing relationships to the speech-act, or similar ones, respectively. As mentioned and illustrated in various places above, the distinction between third person (non-speech-act-participant) and non-third person (speech act participant) meanings in the various person-marking paradigms is indicated in a variety of ways. Consequently, this division can be considered an important organizational parameter useful in describing the Máku person-marking paradigms. When considered for the quality of the relationships to the speech-act in this way, the fact that there is syncretism between the inclusive and the third-person plural is less important. The suggested syncretism represents a set of distinctions that may not be relevant for the Máku system in the first place (see below).

As a means of summary, the following is a list of the salient facts for the person-marking paradigms in Máku as described above.

1. There are five morphemes involved in the person-marking paradigms in Máku, three singular morphemes (te, $e$, and $k e$ ) and two non-singular morphemes (tse and teke).

2. Two suffixes $-n u ? u$ and $-p u$ frequently correspond to plurality though some examples show that they might have a collective connotation, but do not directly reference person (though see number three below).

3. There is a morphologically marked distinction between third persons and non-third persons in the form of affix position in pronoun formation, pronominal roots, and use of the suffixes $n u ? u$ and $-p u$.

4. There is a distinction between inclusive and exclusive forms (tse and teke respectively) without a dedicated first person unified plural form. The unified plural meaning, where it is recorded, is simply agglutination of the first person singular form te and the plural/collective 
suffix $-n u ? u$ on a single root.

5. The meaning of the clusivity markers as references of number is at least partially dependent on the presence of the number suffixes as a component of a given paradigm. In paradigms where the number suffixes are used, the clusivity markers are strictly dual, while in paradigms where the number suffixes are not used, the clusivity makers have plural meanings.

6. The tse 'inclusive' form represents a non-singular distinction where the referents reflect a homogenous relationship to the speech-act. As an inclusive all referents are non-third person and speech-act-participants, as a third person plural all referents are third person and nonspeech-act- participants.

7. The teke 'exclusive' form represents a non-singular distinction where the referents reflect a heterogeneous relationship to the speech-act. One referent is a speech-act-participant while the other referent is not.

These facts suggest a number of contrasts in the meanings of the personal marking forms. The contrasts can be represented as binary values as in Table 19.

\begin{tabular}{lccccccc}
\hline & te & e & ke & tse & teke & -nu?u & - pu \\
\hline Plural/Collective & - & - & - & $-/(+)$ & $-/(+)$ & + & + \\
\hline Singular & + & + & + & - & - & - & - \\
\hline Speaker & + & - & - & $+/-$ & + & + & - \\
\hline Addressee & - & + & + & $+/-$ & - & + & - \\
\hline Other & - & + & - & $+/-$ & + & - & + \\
\hline
\end{tabular}

Table 19. Meaning Contrasts relevant for Maku person-marking.

The PLURAL/COLLECTIVE contrast in the table indicates that those morphemes marked ' + ' primarily reference non-singular numbers. Note that $t$ se and teke possibly do this when a paradigm is not recorded using the suffixes -nu? $u$ and - $p u$ (as for nominal possession), and are marked ' $(+)$ '. The SINGULAR contrast indicates that those morphemes marked ' + ' primarily reference only a single person. The SPEAKER contrast indicates that those morphemes marked ' + ' reference the speaker. The morpheme tse can reference the speaker when used as the inclusive, but does not do so when it is the third person plural marker, and is thus marked ' $+/-$ '. The ADDRESSEE contrast is similar to SPEAKER, except morphemes marked with ' + ' indicate that it references the addressee. Again the morpheme tse references the addressee when used as the inclusive but not when used as third person plural, and so receives the value ' $+/-$ '. The contrast OTHER indicates those morphemes that reference a third person, or non-speech act participant.

The meanings of each of the person-marking morphemes exhibited in the various paradigms above can be defined by their unique set of contrasts indicated in Table 19. For example, te can be defined as meaning 'non-plural, singular, and referencing only the speaker', while tse can be defined as meaning 'not primarily plural, not singular, and referencing the speaker, the addressee, or other (depending on the specific meaning intended)'. Based on these contrasts, and the definitions that result from them, a description of the person-marking system in Máku can be suggested which matches much more closely the language-specific organization. This description is significantly different from the traditional analysis of person-marking suggested in section 1, and employed throughout section 3, and relies only on the descriptive facts and contrasts presented 
above. In specific, Máku exhibits four distinct, though quite similar, person marking paradigms, presented in turn below.

Table 20 represents the person-marking paradigm for subject agreement on verbs. In this table, and in subsequent tables, parentheses indicate optionality.

\begin{tabular}{|l|l|l|l|l|}
\hline \multicolumn{4}{|l|}{ Singular } & \multicolumn{2}{|l|}{$\begin{array}{l}\text { Non-singular } \\
\text { Dual }\end{array}$} & \multicolumn{2}{l|}{ Plural/Collective } \\
\hline speaker & $t e$ & heterogeneous SAP & teke & $-n u ? u$ \\
\hline addressee & $k e$ & homogenous SAP & tse & \\
\hline other & $\varnothing$ & & & $(-p u)$ \\
\hline
\end{tabular}

Table 20. Máku-specific subject agreement person-marking paradigm

This person marking paradigm is used exclusively for verb-subject agreement. However, as noted above the verb class (assuming these were valid diachronically) determines if they are used as prefixes, infixes, or suffixes. In this paradigm the forms teke and tse are strictly dual and contrast with the plural/collective meanings of the suffixes -nu? $u$ and $-p u$.

Table 21 represents the person-marking paradigm for inalienable noun possession and for object agreement. The forms teke and tse are not strictly plural in this paradigm and contrast only with the suffix $-n u ? u$ as a collective for the second person plural meanings.

\begin{tabular}{|c|c|c|c|c|}
\hline \multicolumn{2}{|l|}{ Singular } & \multicolumn{2}{|l|}{ Non-singular/Plural } & Collective \\
\hline speaker & te & heterogeneous SAP & teke & \\
\hline addressee & $e$ & homogenous SAP & tse & $(-n u ? u)$ \\
\hline other & $\varnothing$ & & & \\
\hline
\end{tabular}

Table 21. Inalienable possession and object agreement person-marking paradigm

Table 22 represents the person-marking paradigm for alienable noun possession. The form $e$ means both second person singular and third person singular. Additionally, similar to inalienable possession paradigm represented in Table 21 , the forms teke and tse are not strictly plural in this paradigm and contrast only with the suffix $-n u ? u$ as a collective for the second person plural meanings.

\begin{tabular}{|c|c|c|c|c|}
\hline \multirow{2}{*}{\multicolumn{2}{|c|}{ Singular }} & \multicolumn{3}{|l|}{ Non-singular } \\
\hline & & \multicolumn{2}{|l|}{ Dual/Plural } & Collective \\
\hline speaker & te & heterogeneous SAP & teke & \multirow{3}{*}{$\left.(-n u)^{2} u\right)$} \\
\hline addressee & & homogenous SAP & tse & \\
\hline other & $e$ & & & \\
\hline
\end{tabular}

Lastly, Table 23 represents the person-marking paradigm for pronoun formation. 


\begin{tabular}{|c|c|c|c|c|}
\hline \multirow{2}{*}{\multicolumn{2}{|c|}{ Singular }} & \multicolumn{3}{|l|}{ Non-singular } \\
\hline & & \multicolumn{2}{|l|}{ Dual } & Plural \\
\hline speaker & te & heterogeneous SAP & teke & \multirow[t]{2}{*}{-nu?u } \\
\hline addressee & $e$ & homogenous SAP & tse & \\
\hline other & & & & \\
\hline
\end{tabular}

This paradigm shares similarities with each of the other paradigms. The form $e$ indicates second person singular and third person singular (as in alienable possession in Table 22), except that it occurs as a prefix or suffix, respectively. This difference of position indicates that the meanings correlated with this form in this paradigm, can be descriptively kept distinct, and are consequently separated by a dotted line in the paradigm. Like the subject agreement paradigm in Table 20, the forms teke and tse are strictly dual and contrast with the plural suffix -nu?u (where no evidence indicates it functions with a collective meaning in this paradigm).

Based on the description of contrasts and the representation of the various paradigms in Tables 19 through 23, the lack of additional information on Máku is lamentable. The similarities between these paradigms are obvious. For example, all of them represent a quality distinction referencing the relationship the referents have with the speech-act, as with the morphemes tse and teke. Similarly, the alienable noun possession paradigm and the pronominal paradigm are quite similar, and it is tempting to conflate them into a single paradigm. Perhaps these similarities represent a common diachronic source of person-marking in Máku, but there is simply no evidence or apparent justification for such a conflation.

As a form of conclusion, Máku exhibits an interesting system of person marking which seems to be better represented in a language-specific analysis than through a traditional analysis comprising of three persons and two numbers. Furthermore, when described in this languagespecific way, Máku represents a unique system unattested in crosslinguistic studies of personmarking paradigms. This unique system is built on contrasts between the quality of referents as speech-act-participants or not. Since there are no speakers of Máku remaining, it is speculative to suggest what social functions the various contrasts represented. However, it is likely that at least the salience of quality of referents as speech-act-participants or not would have represented a thoroughly Máku-specific worldview. It would be beneficial for future research to examine this issue in languages with similar contrasts in their person-marking systems.

\section{References}

Cysouw, Michael. 2003. The paradigmatic structure of person marking. (Oxford Studies in Typology and Linguistic Theory). Oxford ; New York: Oxford University Press.

de Faria, João Barbosa. 1927a. Vocabulário da tribo Macú. [Manuscript in Arquivo do Museo do Índio, Rio de Janeiro.]

de Faria, João Barbosa. 1927b. Vocabulário Maiongon e Macú, São Marcos, Rio Branco, Amazonas. 4 de dezembro de 1927. Coletado por João Barbosa de Faria. [Manuscript in Arquivo do Museo do Índio, Rio de Janeiro.]

de Santo Tomás, Domingo.1560. Grammatica, o Arte de la lengua general de los Indios de los reynos del Peru. Impresso en Valladolid, : por Francisco Fernandez de Cordoua, impressor de la M.R. http://archive.org/details/grammaticaoarted00domi. 
Greenberg, Joseph H. 1987. Language in the Americas. Stanford, CA: Stanford University Press. Haspelmath, Martin. 2010. Comparative concepts and descriptive categories in crosslinguistic studies. Language, vol. 86 (3), 663-687.

Kaufman, Terrence. 1994. The native languages of South America. In Christopher Moseley, ed., Atlas of the world's languages, pp. 46-76. London: Routledge.

Koch-Grünberg, Theodor. 1906. Die Makú. Anthropos 1:877-906.

Koch-Grünberg, Theodor. 1911. Aruak-Sprachen Nordwestbrasilien und der angrenzenden Gebiete. Mitteilungen der anthropologischen Geselschaft 41:33-153, 203-82.

Koch-Grünberg, Theodor. 1913. Abschluß meiner Reise durch Nordbrasilien zum Orinoco, mit Berücksichtigung der von mir besuchten Indianerstämme. Zeitschrift für Ethnologie 45:44874.

Koch-Grünberg, Theodor. 1917 Von Roroima zum Orinoco. Ergebnisse einer Reise in Nordbrasilien und Venezuela in den Jahren 1911-1913. Vol. 1: Schilderung der Reise. Berlin: Reimer.

Loukotka, Čestmír. 1968. Classification of South American Indian languages. Johannes Wilbert, ed. Los Angeles: University of California Press.

Maciel, Iraguacema Lima. 1991. Alguns aspectos fonológicos e morfológicos da língua maku. MA thesis, Universidade de Brasília.

Migliazza, Ernesto C. 1965. Fonologia máku. Boletim do Museu Paraense Emílio Goeldi, Antropologia 25:1-18.

Migliazza, Ernesto C. 1966. Esboço sintático de um corpus da língua máku. Boletim do Museu Paraense Emílio Goeldi, Antropologia 32:1-38.

Migliazza, Ernesto C. 1958. Máku field notes. Unpublished manuscript.

Migliazza, Ernesto C. 1978. Maku, Sape and Uruak languages: current status and basic lexicon. Anthropological Linguistics 20:133-40.

Migliazza, Ernesto C. 1980. Languages of the Orinoco-Amazon basin: current status. Antropológica 53:95-162.

Migliazza, Ernesto C. 1980. Languages of the Orinoco-Amazon basin: current status. Antropológica 53:95-162.

Rice, A. Hamilton. 1928. The Rio Branco, Uraricuera, and Parima (second part). The Geographical Journal 71:209-33.

Rodrigues, Aryon D. 1986. Linguas brasileiras: para o conhecimento das línguas indígenas. São Paulo: Edições Loyola.

Rogers, Chris \& Raoul Zamponi. A descriptive grammar of Máku, in preparation.

Siewierska, Anna. 2004. Person. (Cambridge Textbooks in Linguistics). Cambridge ; New York: Cambridge University Press.

Zamponi, Raoul \& Chris Rogers. To appear. Máku. In: Patience Epps and Lev Michael, eds., Amazonian languages: an international handbook. Berlin: De Gruyter Mouton. 